\title{
The Sparrow Ghost
}

Sonia K. Johnson

A thesis submitted to Victoria University of Wellington in fulfillment of the research requirements for the degree of Master of Arts in Creative Writing. 
Schauder u. traum

- Samuel Beckett 


\section{Introduction}

The characters depicted here are based on the particular actions and experiences of actual people, but their personalities and relationships have been fictionalised. No resemblance is ultimately intended between these characters and their real catalysts.

The descriptions of the flu pandemic are as accurate as possible. This work is, however, not intended as an historical account. History is a means, not my end. 


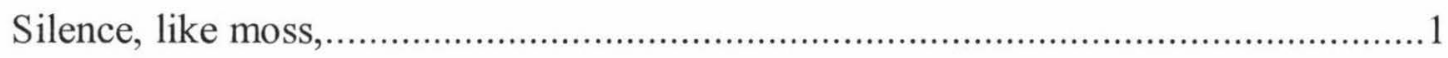

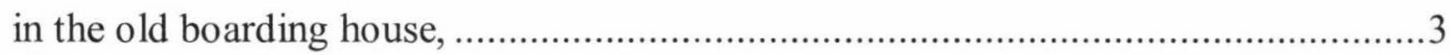

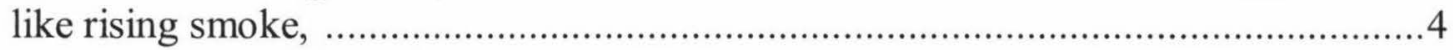

exhumation of broken glass, ............................................................................... 5

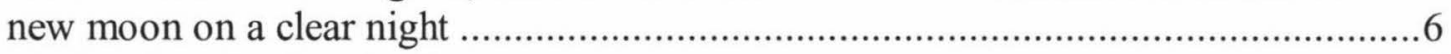

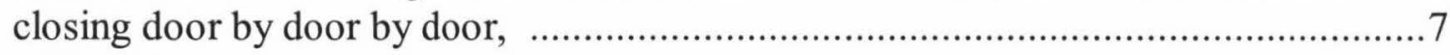

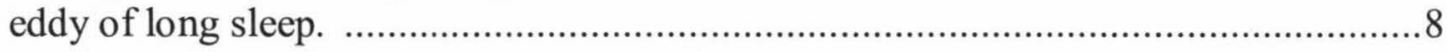

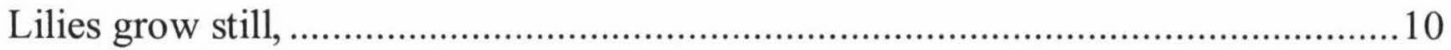

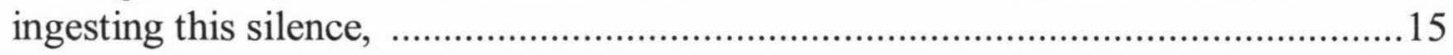

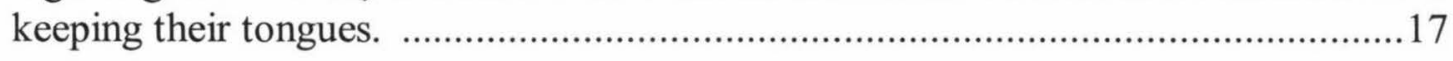

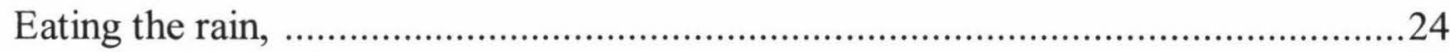

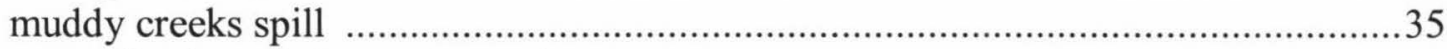

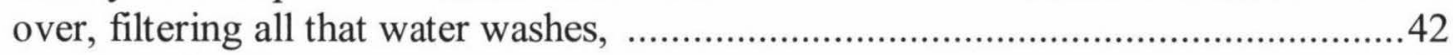

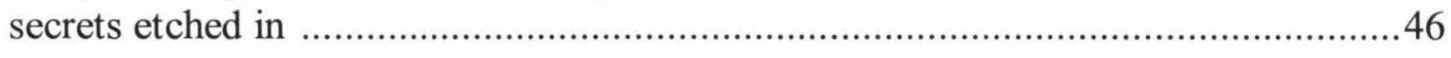

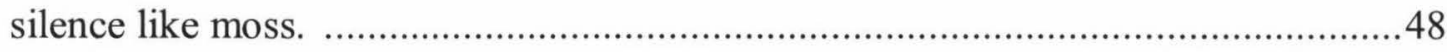


In the old boarding house, night nests between

tight-scarred floor boards.

Hollow walls

enclose darkness.

The day falls,

unfurling grey.

Roof, walls, windows

new-born in day's new form.

In these bones, voices

now stir; rippled

glass coheres light.

$O$, the hills of a daughter's insomnia

fence the valley of sleep

and she opens her eyes.

Here is the nail's grip each door, each stair, all: mute palimpsest vestigial

yet.

Soon hatchlings under the tin eaves begin to cry hunger and a cloud-breeding heat starts to settle over the valley. The sun negates its light. 
Like rising smoke

in a wood-fire kitchen,

so the voices in the house

thicken over time,

ebbing and rising, gathering in

nooks and hollows.

From this mass

of time-worn words emerges

Ruth Newson,

the owner through the last

heave of the Great War and beyond.

Exact, rounded vowels

bitten square by consonants

recall her tight frame

exactly. And from within this,

a softer tone-Mother? - Yes Lily?

knotting familiarity.

In diners' bachelor boots, dirt whispers

now I'd give her a go, alright, the sparrow

ghost that steals the daughter's sleep.

Only the voices now remain,

folded in the turn of the stair:

Mrs Newson, should I

expected it would be nothing but

my father said the railway

oh no, I couldn't

really, did he

yes, she would, oh yes 
Exhumation of broken glass

and all the valley falling,

cauls of dust and spiders' webs

hang in the old corner store.

Vernal roots expand

over and into abandoned walls, into the church where Ruth once prayed.

Catching at new darkness, this white fan echoes the splay of anonymous bones.

Perhaps one day this entropy of other, untended structures will

lap over into the boarding house, letting its secrets leach away

into the heavy clay but

now it still holds back the rain, still

guards its murmurations.

Cows graze where a cottage once

lifted an asymmetrical veranda.

Engineers have bought the dairy factory

and leave cars to rust there.

No one uses the tennis courts.

Out at the last big farm, a house

falls down hidden completely

in a stand of trees.

There are bees nesting in the walls, sole survivors. Their brittle bodies

smell of dry rot.

Kettles rust to paper-thin.

In this place, only

nettles, dock and cooch climb. 
New moon on a clear night in November does not bleach glass to silver, but rather settles blackly here, where the two-train railway that runs through the valley

bisects the sealed road that has collapsed its steel vein.

In a fuller moonlight neat silver might belly the clouds, gild slips where wet surfaces mirror, maybe;

the creeks, cleared and cut here to drain the swamps, ensnare the ground in meshed light,

while the trees would anchor each to their own impermeable thrall of shadow.

In the full moon's hard light, rails and water would shine, rain be a glistening afterthought - but under cover of the new moon, pulling up, the tracks twist themselves of the soil into such shapes of metallic logic as no human mind could bear. 
Closing door by door by door on the frosts of winter, spring

lifts new life from the still-cool dirt. The valley stirs.

Years spill over, grown strange, etiolated. There were lovers and there were deaths, rage and monotony's quiet, slow wearing away.

Slow, quiet convolvulus edges out in sightless seeking, edges out, tracing a helix. Knowledge is all dumb sense in that tender tendril; no signal, no touchstone yet gained to bend to the blind cells.

How to say what and how each stem-hold is granted and determined? The silent thrust requires no answer. 
Eddy of long sleep

shivers tensions of gravity,

closeness and force -

all that holds

place to its foundations.

In the dreaming of this shudder

now the voices that sought

gain a hold and bend.

Feeling a hardness, a sharp edge in the drifting voices, now the line of memory coils around it $-\mathrm{a}$ babble of fever lifting the night, the impact lingering of a falling body, yes, and the breaking of glass.

Wind there balances the silence interlacing the two, the mother and the daughter who hear the strumming of rain

three weeks without end, holding the truing of spring into summer, holding spring's wet death tenderly. 
Lilies grow still, imitating sky

lost in the equilibrium of rain

yet to fall, in a suspended saturation.

Over Lily, the laughter of children

fades, winding out of the schoolyard.

The rush of November startles

her into flight.

Electric spring runs through her.

Vegetable elation rises, and a quickening

layers new flesh to her.

Light through waiting rain

enflames new growth -

yellows and greens burn.

Grace of near horizons

recurs in the turning of her shoulder

or in the angles of her bones

when she stands, when

she pauses as though foundered

in the burgeoning of her

newling frame.

The blossoms scatter white across

her dress as she twists

each spray, making a stiff bunch

she thinks she will keep by her bed.

Her mind falls back to the bright spot of blood

and she

does not hear the pain

exquisite in the branch as she breaks.

Out in the long embrace of hills, she

finds no escape-that's because you're a woman now,

this means you can get pregnant.

Her mother's face had been as careful as her voice, 
except that her hands had shaken.

Breaking, the limbs bleed a little of the sap that rises.

A sky as still as windless grass rests on the shoulders of the hills, deep, not dull, in its grey.

It cannot soothe her.

Now what? And why this pain, grinding? What did I do?

Her eyes, though blue,

out-grey the sky, growing opaque.

Under the clouds she pauses,

suddenly caught, lambent, a small flame

enclosed, enlarged by the mirroring hills. 
Kicking, roots shift.

Inner leaves open.

Nerves glut.

Day dilates.

Lichen eats.

Insects hatch.

Nicks saw flax.

Green kicks, breaking. 
And she moves. She breaks the hush,

precipitating the unbalancing of the sky.

A filter falls over the violent green

lit by clouds and extinguished by rain.

Extinguished? Rather enclosed, growing

long and bright out of view.

In Lily's bend the rain is cambered: she gives direction to gravity,

her swelling breasts channeling

tributaries to her sodden skirts.

The quickening in her coils, her breath caught fast as the chill

exploration of water

reaches through and past bleached cotton,

eventually blooming darkly red.

Bunching of breast or shoulder

echoed dimly in the hill-line

touches something in her.

Will I get married now? To who?

Emma's married, and she's not

eighteen yet. The rain

now blurs her

eyes, runs into her mouth

and she stretches out her arms,

reaching to hold

the sky. Water pools in the hollows

her taut tendons make.

And water mats the toi-toi, new growth bruises, the rain batters

daffodils' fleshy stems.

Heavy and heavier, a beat under the beat of her pulse, mixing with the push of her heart and in her hand the fragile blossom now crumples,

washing clean, washing 
away the loose petals that had remained.

Lily does not see this,

lost in the beating, in the humming

susurrus of rain and earth and skin

and she has closed her eyes,

now all mute skin, all wet skin

drinking in as the rain

splashes the white of the lilies,

kisses the waxy pallor and

You get in now, Lily, NOW. 
Ingesting this silence,

this narrow coddling of hills

in hills under a close

sky, Jim the old odd jobber

hears the drum of rain

echoing on the tin

roof of his rented bach.

Each of the timbers is

joined at all the proper angles

in all the proper places. He

muses on spring with all the old

habits of his once-young mind

as the rain lowers its mists. His

ugly, yellowed hands lie dormant.

Nancy, in Wellington, had said once

that he had such lovely hands...

Summoned by her mother's call

his landlady's daughter runs by, her

edges blurred by rain but her

long dress pulled tight over her thighs.

Day lengthens in spring, but nothing thaws in his bones.

Only, what else is left?

Well, there is the pub. 
Lost behind the valley hills

and clouds, the mountain remains,

the stubborn remainder of old

eruptions and erosions, tales

recalled in the flight of hands

in a barroom fire's warmth.

Now Jim remembers the time he

climbed the mountain and the land

lay open, all blued with distance,

open. In the following winter, a sudden

storm caught three climbers out,

Englishmen. They died, bodies lost.

Rain catches on the peak,

winging out inland over the valley.

Anyway, it's time for another smoke.

Long, too long until tomorrow, too

long until tonight, when the moon,

shrinking into new, will leave him dark. 
Keeping their tongues,

noting the crude release

of rain groping

the windows' flaws,

the cut lilies listen.

Exactly what were you

doing, Lily, getting yourself all wet...

This is how you act? And you all of sixteen!

- I was just... - Yes?

- Mother, please, I was only...

but her voice fades down, ebbing into the rain's patter.

Really, Lily, anyone could have

seen you out there, your dress all...

Sorry, Mother, I won't...

The cones of the lilies are tight in their polished vases.

Lily, change at once, catch your death,

look at you! Well, get ready, you'll

help serve the dinner tonight.

Oh, and throw away those branches,

Lily, don't bring things like that in. I

don't know where you get these ideas... 
$*$

In Ruth's boarding house, the doors number guests off neatly, dividing

the upstairs corridor into

headcounts and table places,

each clean, ledgered numeral

measured into days and nights

and the linen to be washed.

In this wet afternoon

nothing moves in the hall.

Here, after the zenith has passed

on, only Ruth moves, her footsteps undertone on the well-swept carpet, secrets whispered into the child's ear who listens through the keyhole. 
Silverware shines clean

in the guests' dining room.

The evening and the rain settle in,

just touching on dark

under the hills' and clouds'

shadows.

The Brittania steel

and lucid glass hold

back the fall of evening for a little.

Only Ruth now, in the pre-dinner hour, variegates the thin gleams

each time her shadow passes.

Table by table,

her eye, keenly trained,

exacts symmetry.

Forks raise slender arcs,

lifting away from the horizon

of polished wood.

Overhead, the high stud

diminishes into dimness.

Linen napkins splash

in bleached blossoming.

Not quite satisfied, she straightens

each edge once more. 
After dinner,

nightfall.

Deep night

swallowing.

The diners

rest fitful,

aware of the dark

in some

nadir of sleep.

Kernel night,

eternal

enclosure

no spring wakes.

Eve of

yes and no and

everything

slips. 
Over the valley, the boarding house,

Newson's homestead, the bach,

the corner store and all, dawn

huddles into wet waking.

Egmont is lost still,

clouds beyond hills shrouding.

Ruth Newson wakes

early, always

earliest in her house,

preparing her self

in the shifting light.

Not a sound as she laces,

grips, cleans and kempts.

Once built and square, Ruth

finally looks into the mirror

to see, in the chalky reflection, her eyes grown hard and nested, eyes of carpentry and steel.

What makes her stare so long and then turn away?

The mirror spits her out, echoing the clean wall once more.

Ruth's footsteps in the hall

shake her daughter from sleep. 
Out into the unstable morning, following the worn path, Ruth

sets out for the boarding house.

Pushing into the kitchen, the heat

remaining from last night greets her.

In she walks at six each day, belying

now and never the loss of days in her punctual

gesture, in her echo of herself, of herself again. 
Eating the rain, vegetation

extends hungry hands.

Over fire-cleared earth,

fingering, it inches forward.

Spanish flu, a hissing, falling

overflowing sound,

mingles with the talk of milk prices,

ewes and the slips over at Jack's,

vanishing finally into closing lips.

It's just up Auckland,

nothing to it'll spread this far.

Eddie said to never mind, it's not so bad,

some aspirin and bed rest's all...

Then closer to home,

reaching as far as cousins,

uncles, friends, and closer.

November eighteenth:

God, did you hear?

They said he died sudden, skin turned black,

ebony she said he was, and right in town!

Now it's wives and husbands,

sisters, mothers, all

in the fevers and it comes

on so suddenly just fell over, he was fine

no warning, all the young ones, strong, the doctor

reckons, hits the healthy ones worst

Everyone wants pills, wants camphor, wants

lemons and oranges, the price of them!

Everyone at the inhalation chambers

a gulp of formalin, that sort of gas thing

Sulphur on the fire smokes

epidemic's bad in the city, Sally said,

she saw the special train out to the cemetery.

If you bleed at the nose, you'll be fine.

Now, just wear this little bag, you'll be safe... 
Thick fluids rattle in lungs,

hearsay of bodies dumped in the sea,

emergency morgues in city parks and

Doctor, they have taken out the lining from my inside!

and the smell of the houses

rancid with illness, flimsy houses

keeping all that green so slightly at bay. 
Two wide-built men struggle

heavy bed-frames around the landing,

expletives muffled by Ruth's presence as she

directs them to take care

in not scratching the banisters.

No need to be careless, Tom.

In the dining room,

narrow needful beds line up,

gleaming pale with clean linen.

Ruth moves the sick guests

out last, supporting them

or having them carried.

Movement disorients.

In the dining room, Jim helps

shift the last bed into place,

shuffling his old man's walk

to and fro, pushing a little here and there.

In the hall outside,

Lily hangs back, frightened by the sweat-smell

lifting from the men and by their unfamiliar sounds.

The men are tired.

Heavy vowels slacken

rough-already voices.

Over this slow bass

unleashes a bright,

glissando of delirium,

haunting the silence after.

The beds are straight, the sheets

hospital clean.

Emergency hospital.

Doctor's visits once a week

and volunteers to nurse,

young and old,

smiling tightly as they tend. 
Lily holds a smudged glass

up to Tom's mouth.

Mother said for you to drink, oh

but you're so hot and won't you drink?

Even this lemon drink? And lemons so

rare now and he won't drink.

- Come now girl, he's in no state for that.

And the doctor's back again, a week already, ugly man, he's all teeth and hair.

Give him an enema, like I told you,

he won't take anything like that,

the doctor says, already leaving.

But Lily doesn't know what

enema means - something like

the Germans, like an enemy?

Well, just keep at it,

excellent work, no fatalities yet,

excellent work and he's gone,

nothing for another week.

Up at the homestead, her mother

sleeps, just an hour or two

each day and Lily is in charge

and she doesn't know.

Ned keeps shouting that his

Da's up the cowshed, Da's up the

Rose is starting to turn black, ends of her fingers

first, but it's spreading

under her skin, clouding up,

smoky sort of a black,

a kitchen window left too long.

Lily turns away.

Wendy is asking if she might

ask for some water.

I hate to, Annie, love, but...

the sheets under her

sweat and seam. 
The door slams, shifting heavy, foetid air, and Ruth

enters, the hem of her skirt muddy and eyes

raw with sleep. Mother, the doctor said that Tom needs...

enema...? - Then do it, Lily. 
Her tight bun now unraveling, eyes sunk with exhaustion, Ruth, carrying a basin, enters the sickroom again

and

pin-thin wrinkles crack in the bodice of her dress as she tips out of balance now drag of inertia on the fibres of her fabric when she bends into breaking the basin hanging now hands spread unknit to splinter fans

make sharp angles her elbows break loose of her waist elapse rigid symmetries erode sawn and dead straight lines keeling eyes roll back yellow whites in sanded frames water coils out of the basin and her knees not holding

on

no

longer lumber yearning for release eyes close face variegates in light she eclipses and fluid rest forces down rusted failures explosions and scattered migrations fling 
out of shards of tin

falls bright the water

under candles

now the basin hits

steel ring

the bone crack

as knees hit

in one-two and

now hip

elbow

down

in the wet

vegetable slap

of flesh

resounds through

years and hard wood. 
As Ruth fell, Lily

saw the breaking of her.

It broke her,

that sound of impact.

Fever did not come

and the doctor said exhaustion,

it was only exhaustion.

Lily could not shake the hard

sound of flesh meeting wood. 
Slow-fast weeks

in the dining room,

Lily and Ruth and others

eke small life out.

No death has yet darkened this dark room,

claustrophobic with thought of it

eating into flesh.

Perhaps dawn will never come, never

rise above the school house. Lily

endures this thought each night.

She is hollow eyed

in the loud

delirium, keeping the patients in their beds,

emptying the pans and basins

spit-heavy,

wiping away bright

haemorrhages with dirty towels.

Enema, she has found,

requires a terrible knowledge;

each body with its own textures and smells,

own tics and slow movements. They are, at least, not aware of her dark intrusion. She

carries the bottle to

Edward, who needs to piss but

me arms, me hands, I can't...

Edward's skin is hot with fever

now, hotter there

and the bottle splashes warm, cooling

to tepid as she carries it over,

empties it in the bucket.

There is dirt on her skin, under

her nails all the time,

even when she has cleaned them.

Red when fresh, blood dries

a maroon, browny colour,

verging on black in the dim room.

Each of the beds darkens 
night by night, sweat and blood, into the weave, seaming.

No dawn, surely, can be granted after this.

She no longer

hears words

among the cries.

Day could not

enlighten this.

Only if day would break, filling the room with colour.

She is alone

in this night, her mother

lying up at the homestead -

exhaustion, she must rest, Lily you...

Nola sick too.

Catherine at home tonight.

Each of the beds darkens.

Lily dips a sponge

into a dented basin, not

knowing what

else to do.

Mrs Wells is awake,

out of the delirium, but now

she's losing all her hair.

She collects it in a shoebox.

If dawn could

never come again.

The voices spill out,

hiding in the chinks,

eaves, the small places.

The voices swell and swell, only there is no breaking, no breaking in sight.

Grown numb to flesh, Lily

undoes the buttons,

eases out soft,

secrets 
of men and women and she

feels their sweat soak in

to her skin and it won't wash

off, won't wash out

no matter how hard she washes.

Grown deaf to the voices, Lily is

unflinching now,

even against Rose's sudden screaming

and Lily moves like a ghost

now, as though

dawn would scatter her.

Grey dawn

rises finally and brings

on the threshold her mother staring

Oh Lily... Your hair, your hair, Lily...

Very soon, too, the wives and daughters of the valley

eccho overnight, she turned grey overnight. 


\section{II}

Muddy creeks spill

an overflow of waters,

now the spring rains are in.

The weeks wear on.

Late one afternoon, Jim

exhausts his luck and falls

down outside the pub.

The publican calls his brother

in, says to take him home.

Mick, the brother, is busy,

but they can't just leave him there.

'e was fine just now, fit as a

Resting in Newson's dining room, his sleep is broken by the fever in him. 
And his skin burns and crawls reaching into his dreams, no

escaping his skin, twisting eating at him, gnawing in.

And the cool hands on him scutter, thrilling chills

into his bones, the room pulses loud around and growing young his flesh fills out but earwigs are hatching in the walls, new and glossy in the walls. The woman beside his bed

extracts a dark, lithe body richly smooth - and cracks open. 
Even his bones are burning now, dug under skin and muscle

in a darker darkness.

Now his skin begins to smoke,

murky, unclean wood-smoke, unclean fires in him.

The woman who bends is every woman who has bent

since he was sixteen and Jimmy

is a good boy, ooh such a good boy

lilting, lilting, oh Jimmy lad

every sweaty hand and tit

No but the woman with the black eyes crawls insectile into him. 
Every wall of him is torn open.

Spiders breed in hollowed organs.

Pulsing, plush tissue plumps

inside him, crawling, crawling and

Damn things 've laid their

eggs in him, and he

rips at the gauzy egg-sacs,

stands to fight and she

bends him back down,

right back, he's lying back, he's

every Jim he ever was, he's

electric bright as pain lightning

down his bones twists,

enthralls his bones, cold. 
And his skin falls away, rips off in broad strips,

wallpaper rots away

in wide swathes.

Gristle shines in the blood, showing dusky, dirty,

something moving there, clicking and swift, jointed

and glossy fast, darkening the bright blood-rich muscle.

the skin keeps dropping, dropping exposes shifting, dropping

red, darkening, swarming. Skin coils away and his flesh shines. 
And the meat drops away

now, bones slip through,

now the bones slip

out and she's watching him,

nipples red and her lips and she

echoes, echoes oh, Jim

oh, Jimmy, such a good lad,

flesh in her hands, in her

tongue, between

her teeth rip wide, spiders

in between her molars pop and he

screams and he screams and

he screams and she smiles

over him, sighing oh, Jimmy. 
Lily asks How are you now?

dabbing a sponge on his forehead.

The walls have grown still again.

Only Lily sits beside him.

Weeks and months will recover him and though he'll never be

the old Jim, he'll continue his slower erosion, sinking quietly year by year.

Right, for now, seems right enough. the skin on his hands

is yellow, scarred, gnarled but it's there,

hiding the blood and hiding the thing that scuttles in him. 
Over, filtering all that water washes -

linen, cups, faces, floors - back into the light,

December remains somehow stained.

Now is to clean and to straighten.

In the afterwards,

grunts and curt directions

herald the return of the beds

to the upstairs rooms. 
Birds, fragile hatchlings,

escape or are exiled from the eaves,

claiming a small moment

of flight before gravity hits.

Mornings find their translucent

eggshell bodies

surrounding the boarding house. 
Evening and Lily, where have been for so long?

- At the store, Mother, like you asked.

Ruth draws the tendons in her neck tight, under slackening skin.

- Lily, did you get the extra sugar? I need that.

- Yes, mother, it's all there.

Minutes silently pass as Ruth inspects.

One by one, she weighs the packages in the basket, reckoning some short, looking askance at Lily, and saying

No-one's to be trusted, Lily, you have to watch for their thumbs. - I will, Mother.

Now Ruth cannot weigh and prod any longer, and Lily goes again, pale and sufficient in the twilight. 
Darkness draws out the days and summer warms the raw green.

Yellow softens the hills at twilight.

Blackness draws back, recoiling into shorter hours.

Each day hardens Ruth's rule: an error is always seen, known and punished. Darkness sleeps, only waiting. 
Secrets etched in

unbroken rain run under and Jim

now drinks hard. Tonight he

risks bringing home a dozen.

In the twilight Ruth enters. She'd

seen the crate. She takes two bottles -

exact, anatomical grip of her

hands. Then out again. Shatter

as her sinews flex. The salt

smell of his tears in his folded face

and the yeast smell mix. She goes

right past him without looking.

Echoes again and again that shatter.

Drench of beer soaking into moss.

Dirt drinks. She doesn't say a word.

And it's Jim, not Ruth, who sees Lily

watching from the boarder's window, naked, before she snaps the curtains shut. 
Silence like moss

in the turning of a heavy season -

listen for the breaking of memory, each voice pulling clean of its skin.

Night brings the wet irruption,

cold years seeking heat,

escaping finally with this.

Lily of the Valley grows

in the shade of the boarding house,

kindling a pale light there between

earth and human walls and sky.

It is here Jim haunts, held

now, later, in closer walls.

Knotted timbers still hold in the main house,

sit just above the flood line and strain

keen eyes on the creeping of the waters of spring.

Eve of some vine-strung tension releases in the dark.

The dining room is still through the days, lumber

caught between use and refusal waits there;

here a piano with numbered keys can only

ever dream of unstained ivory as it fails.

Silence presides where once men ate,

the ravening shade of silence like moss

in the tongues of tongue and groove.

Mantled timbers are easily

entered in mute silence;

spiders breed,

earwigs scatter,

Can none of this

hold to water-tight?

Old night becomes

early morning,

Day breaks.

Sunrise

has

a

red

dawn.

Silence. 


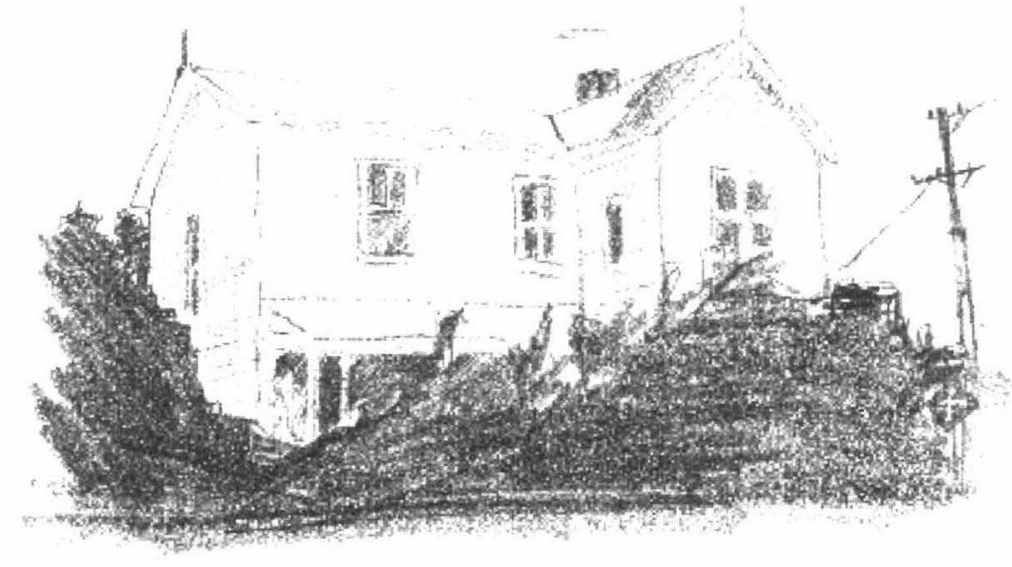




\section{$\underline{\text { Notes }}$}

The place, events and descriptions that the setting, narrative and the three main characters are based on can be found in the 'Douglas Boarding House' section of Douglas: A Taranaki Rural Community, a short history published to celebrate the $75^{\text {th }}$ anniversary of the Douglas School.

The project as a whole, and especially pages 24 to 41 , draw heavily on Geoffrey Rice's excellent history of the flu pandemic in New Zealand, Black November: The 1918 influenza pandemic in New Zealand and Jim Henderson's 1967 radio documentary The Great Plague (excerpts available as text and audio files at www.nzhistory.net.nz).

The epigraph is taken from Samuel Beckett's theatrical notebook for Krapp's Last Tape (Faber and Faber, 1992).

Page 10: Ruth's reported speech here is adapted from an account given in Vicki Marie Culling's doctoral thesis, Writing/righting menstruation: a feminist analysis of New Zealand women's knowledge of the menstrual cycle (Victoria University of Wellington, 2001).

Page 24: 'a gulp of formalin spray' is taken from Audrey Drummond's account in Black November; 'sort of gas' is taken from an anonymous account in Henderson documentary.

Page 25: 'Doctor, they have taken out the lining from my inside!' is taken from Dr David Lloyd Clay's account in Black November.

Page 34: 'turned grey overnight' is taken from Douglas: A Taranaki Rural Community.

Page 49: the Douglas Boarding House. 


\section{Acknowledgements}

I would to thank my supervisor, Dora Malech, and my class-mates, who have been an essential source of critique and encouragement.

Thanks also to Ryan Hartigan, K. R. M. Conaglen, Saskia Voorendt and Anna

Jackson for their time and advice, and to my sister, Holly, for her botanical expertise. 